\title{
Autoantibodies reacting with heart muscle tissue in coronary heart disease
}

\author{
I. STRAUSZ AND GY. DÓBIÁS \\ From the Postgraduate Medical School, Budapest, Hungary
}

SYNOPSIS By the use of the thrombocyte consumption test (T.C.T.) autoantibodies reacting with heart muscle tissue have been demonstrated in $63.3 \%$ of the cases of coronary heart disease accompanied by different grades of insufficiency of the blood supply to the heart muscle. These autoantibodies could be detected two to three weeks after the onset in most patients experiencing a coronary attack for the first time, and persisted for about three to eight weeks following single attacks, whereas following recurrence in patients affected for several months or years the autoantibodies appeared in the serum most frequently within one week, and when the painful attacks were repeated, the T.C.T. remained positive for months, with only short interruptions.

In cases of acute myocardial infarction the finding of a positive T.C.T. and its duration did not depend on the severity of the clinical symptoms nor on the measure of the laboratory changes but positive results were obtained more frequently in patients with acute coronary insufficiency (intermediate coronary syndrome) or angina pectoris with intense pain and frequent attacks than in patients in whom the attacks were infrequent producing slight symptoms.

There was no evidence that these autoantibodies had any damaging effect.

According to the investigations by workers in Hungary and abroad (Butler and Moeschlin, 1956; Dóbiás, Balló, Bertalan, and Loránt, 1965 a, b; Ehrenfeld, Gery, and Davies, 1961 ; Van der Geld, 1964; Hess, Fink, Taranta, and Ziff, 1964; Kleinsorge and Dornbusch, 1960; Osztovics and Szutrély, 1960; Osztovics, Marcsek, and Szász, 1962; Osztovics and Marcsek, 1962; Polzer and Steffen, 1958; Robinson and Brigden, 1963) circulating autoantibodies reacting with heart muscle tissue can be demonstrated in certain heart diseases although their clinical significance is not yet clear. Some authors claim that they might play a pathogenetic role in the postpericardiotomy and postmyocardial infarction syndromes (Dressler, 1959; Van der Geld, 1964; Robinson and Brigden, 1963), but this hypothesis could not be proved unequivocally by animal experiments (Davies, Laufer, Gery and Rosenmann, 1964; Gery, Davies, and Ehrenfeld, 1960; Kaplan, 1958; Kaplan and Craig, 1963); on the other hand, the presence of these antibodies, especially in coronary disease is not accompanied by clinical symptoms, which would confirm their pathogenetic role.

In this paper we propose to describe our own investigations to determine, using a serological

Received for publication 13 October 1966. method (Dóbiás, $1963 \mathrm{a}, \mathrm{b}$ ), how frequently the antibodies reacting with heart muscle can be demonstrated in the presence of myocardial lesions of variable severity due to an insufficient blood supply to the heart muscle, and whether there is a correlation between their presence, the clinical symptoms, and the course of the disease.

\section{PATIENTS AND METHODS}

Ninety patients were studied suffering from deficient blood supply to the heart muscle of variable severity due to arteriosclerotic coronary disease: 42 patients with acute myocardial infarction; 12 with acute coronary insufficiency (the intermediate coronary syndrome) in which there is prolonged pain, the pathological $Q$ wave fails to develop, usually deep negative $T$ waves can be detected by precordial leads, which may persist even for weeks, whereas laboratory findings are within normal limits; 10 with angina pectoris; and 26 patients with coronary sclerosis, that is to say, with unchanging E.C.G. findings and the symptoms of heart failure of variable severity in the foreground, but in a painless stage. We also tested 11 patients with valvular heart disease of rheumatic origin, without the symptoms 
of active rheumatism. The controls were 108 healthy blood donors.

Beside the E.C.G. studies, the subjects were regularly tested for erythrocyte sedimentation rate, SGOT, SGPT, blood sugar, and leucocyte count.

\section{IMMUNOLOGICAL STUDIES}

THROMBOCYTE ADHERENCE CONSUMPTION TEST This test is based on the observation that in the presence of complement the thrombocytes can form non-specific linkages with antigen-antibody systems. When corpuscular antigens are used, the antigen-antibody complex, with the thrombocytes attached to them, will settle after a time at the bottom of the tube, and the thrombocyte count will decrease in the supernatant.

Test serum, $0.5 \mathrm{ml}$., is made up of $0.1 \mathrm{ml}$. fresh human platelet-containing plasma, and $0.4 \mathrm{ml}$. antigenic suspension with a dry material content of 5 to $10 \mathrm{mg}$. $/ \mathrm{ml}$. The thrombocytes are counted in the supernatant of the test serum mixed with fresh human plasma of known thrombocyte count and antigen, and the result is compared with the arithmetic mean of the thrombocyte counts of the supernatants of sera from five similarly treated normal individuals. In cases in which the thrombocyte count of the supernatant of the serum is $85 \%$ of the control mean or less the reaction is considered positive; if it amounts to $86 \%$ the reaction is called uncertain; if it is found to be between 87 and $100 \%$, it is regarded as a negative reaction.

To reduce the possibility of error to a minimum one pipette was used for each measurement, washing it thoroughly with physiological $\mathrm{NaCl}$ solution after having added one ingredient. The method has already been described (Dóbiás, 1963a, b).

ANTIHUMAN GLOBULIN CONSUMPTION TEST (A.G.C.T.) The antigen and the test serum were incubated at $37^{\circ} \mathrm{C}$., and the sediment obtained washed six times in $+4^{\circ} \mathrm{C}$. physiological $\mathrm{NaCl}$ solution; this was followed by the addition of antihuman globulin of known titre. After incubation at room temperature for half an hour the supernatants were diluted serially in steps of $1: 2$ and the antihuman globulin titres were determined again by the use of human $\mathbf{O} R$ (D) + erythrocytes sensitized with anti-D serum. If the latter was found to be two or more titres lower than the control, the serum was considered to have reacted positively; in the opposite case it was considered to have reacted negatively (Steffen, 1955; Steffen and Schindler, 1955).

ANTIGENS Four and seven hours respectively after death due to myocardial infarction, the apparently normal ventricular muscle from two individuals was separated from the area of infarction and the two parts were homogenized in a Waring blender, then washed seven times with $+4^{\circ} \mathrm{C}$. physiological $\mathrm{NaCl}$ solution. After the last washing the supernatant was removed from the heart muscle suspension, the muscle homogenate was divided into $1 \mathrm{ml}$. portions, and was stored at $-20^{\circ} \mathrm{C}$.

During the patients' stay in hospital the tests were repeated at intervals of three to seven days (in eight cases monthly, from six months to over two years). With T.C.T., 507, and with A.G.C.T., 149 samples of serum were examined.

\section{RESULTS}

The results with the T.C.T.s are summarized in Table I. In the group of patients with coronary disease the results were positive in $63.3 \%$; in the control group the results were positive in $2.5 \%$. When the various coronary diseases were grouped according to the degree of the insufficient blood supply and the time of onset of the attack, it was found that the results of the T.C.T. were more

TABLE I

RESULTS OF THE THROMBOCYTE CONSUMPTION TEST

\begin{tabular}{lcccc} 
Diagnosis & $\begin{array}{c}\text { Number } \\
\text { of } \\
\text { Cases }\end{array}$ & \multicolumn{2}{l}{ Result of T.C.T. } \\
\cline { 4 - 5 } & & & Positive & Uncertain ( \pm ) Negative \\
\hline $\begin{array}{l}\text { Acute myocardial } \\
\text { infarction }\end{array}$ & 42 & 34 & 0 & 8 \\
$\begin{array}{l}\text { Acute coronary } \\
\text { insufficiency } \\
\text { (intermediate coronary }\end{array}$ & & & & \\
$\begin{array}{l}\text { syndrome) } \\
\text { Angina pectoris }\end{array}$ & 12 & 9 & 1 & 2 \\
$\begin{array}{l}\text { Coronary sclerosis } \\
\text { Total }\end{array}$ & 10 & 6 & 1 & 3 \\
& 90 & 8 & 2 & 16 \\
$\begin{array}{l}\text { Valvular heart disease } \\
\text { Healthy blood donors } \\
\text { Total }\end{array}$ & 11 & $(63.3 \%)$ & $(4.4 \%)$ & $(32.2 \%$ \\
& 119 & 3 & 0 & 11 \\
& & $(2.5 \%)$ & 0 & 105 \\
& & & & $(97.5 \%)$
\end{tabular}

frequently positive in those cases in which the damage to the heart muscle was of greater severity, just as in any process in progress, compared with inveterate, stationary states. Correspondingly, the results were positive in $81 \%$ of cases with acute myocardial infarction and in only $30 \%$ of cases of coronary sclerosis.

Cases of acute myocardial infarction and of acute coronary insufficiency (the intermediate coronary syndrome) were suitable for investigation of the time

\section{TABLE II}

APPEARANCE OF POSITIVE THROMBOCYTE CONSUMPTION TEST AFTER ONSET OF COMPLAINTS IN CASES OF ACUTE MYOCARDIAL INFARCTION AND IN ACUTE CORONARY INSUFFICIENCY

\begin{tabular}{|c|c|c|}
\hline \multirow{2}{*}{$\begin{array}{l}\text { Appearance of Antibodies } \\
\text { Reacting with Heart } \\
\text { Muscle Tissue after } \\
\text { Onset of Complaints }\end{array}$} & \multicolumn{2}{|c|}{ Number of Cases } \\
\hline & $\begin{array}{l}\text { Without } \\
\text { Previous } \\
\text { Coronary } \\
\text { Disease }\end{array}$ & $\begin{array}{l}\text { With } \\
\text { Previous } \\
\text { Coronary } \\
\text { Disease }\end{array}$ \\
\hline $\begin{aligned}<1 & \text { week } \\
1 & \text { to } 2 \text { weeks } \\
2 & \text { to } 3 \text { weeks } \\
>3 & \text { weeks }\end{aligned}$ & $\begin{array}{r}3 \\
2 \\
8 \\
12\end{array}$ & $\begin{array}{l}9 \\
4 \\
3 \\
2\end{array}$ \\
\hline
\end{tabular}


after onset at which a positive T.C.T. could be obtained for the first time. It could be demonstrated that in those cases in which the result was positive within a week of onset, there was good evidence indicative of a previous coronary affection. In the cases in which the positive reaction appeared after two to three weeks, there was usually no evidence suggestive of previous coronary disease (Table II). There was a direct relationship between the persistence of antibodies and the duration of symptoms. In cases with only one or two painful attacks, the positive T.C.T. turned negative after three to eight weeks, whereas in cases in which the attacks had been coming on over protracted periods of time, the T.C.T. stayed positive for months or years, with only short interruptions.

There was no difference as regards clinical symptoms, laboratory findings, and course of the disease between the two groups of patients with myocardial infarction separated on the basis of the results of the T.C.T. It is emphasized that in the cases of acute coronary insufficiency (intermediate coronary syndrome) and of angina pectoris the laboratory tests (SGOT, E.S.R.) yielded normal results, yet in most of them the T.C.T. was positive.

In some cases sera from the patients were tested not only against normal heart muscle tissue antigen but also against the antigen prepared from the area of infarction. The T.C.T. reaction was about four times more often positive with the normal heart muscle tissue than with the antigen isolated from the area of infarction (Table III).

\section{TABLE III}

COMPARISON OF THE RESULTS OF THE THROMBOCYTE CONSUMPTION TESTS OBTAINED BY THE USE OF ANTIGENS PREPARED FROM INTACT OR NECROTIC HEART MUSCLE TISSUE AREAS

\begin{tabular}{|c|c|c|c|}
\hline \multicolumn{2}{|c|}{ Intact Heart Muscle Tissue } & \multicolumn{2}{|c|}{ Necrotic Heart Muscle Tissue } \\
\hline Positive & Negative & Positive & Negative \\
\hline $\begin{array}{l}17(20.9 \%) \\
1 \text { Three week }\end{array}$ & $\begin{array}{c}64(79 \cdot 1 \%) \\
\text { after the onse }\end{array}$ & $\begin{array}{c}4(4.9 \%) \\
\text { nfarction. }\end{array}$ & $77(95 \cdot 1 \%)$ \\
\hline
\end{tabular}

In 149 unselected cases the A.G.C.T. test was performed simultaneously with the T.C.T. In $75.5 \%$ of those cases the results of the two tests were in agreement (Table IV). In the cases in which they

\section{TABLE IV}

COMPARISON OF THE RESULTS OF THE ANTIHUMAN GLOBULIN CONSUMPTION AND THROMBOCYTE CONSUMPTION TESTS

\begin{tabular}{lccc}
$\begin{array}{l}\text { Both Tests } \\
\text { Positive }\end{array}$ & $\begin{array}{l}\text { Both Tests } \\
\text { Negative }\end{array}$ & $\begin{array}{l}\text { T.C.T. Positive } \\
\text { A.G.C.T. Negative }\end{array}$ & $\begin{array}{l}\text { T.C.T. Negative } \\
\text { A.G.C.T. Positive }\end{array}$ \\
\hline 27 & 62 & 12 & 17 \\
Totals $89(75.5 \%)$ & $29(24.5 \%)$ &
\end{tabular}

diverged the A.G.C.T. was more often positive than was the T.C.T. It is to be noted that the results of the two tests agreed in $69.2 \%$ of the tests involving sera from children with carditis (Dóbiás et al., 1965 $a, b)$.

The A.G.C.T. seems to be more sensitive but less specific than the T.C.T.; this is indicated by the fact that during the course of the disease the former yielded positive results earlier, and in accordance with our earlier investigations (Dóbiás, 1963a, b; Dóbiás et al., 1965a, b; Szécsey, Dóbiás and Kerekes, 1966) in a larger percentage of the cases than the T.C.T., but the number of the positive reactions was about the same percentage higher in the control group as well. Of the sera from 31 healthy blood donors four were positive by the A.G.C.T. (12.9\%), compared with the three sera of 108 proved positive by the T.C.T. $(2 \cdot 7 \%)$.

As to the reproducibility of the T.C.T., repeated tests on 29 positively reacting sera yielded results identical with the previous ones in 26 cases $(89.9 \%)$. In the tests involving sera from patients with liver disease (Dóbiás, 1963a, b) the results were reproducible in $76.8 \%$.

\section{DISCUSSION}

In agreement with earlier experience (Dóbiás, 1963 a, b; Dóbiás et al., 1965a, b; Szécsey et al., 1966), the results now obtained suggest that the T.C.T. is suitable for the detection of antibodies reacting with tissue antigens. The method has the advantage of yielding positive results in a lower percentage of the control cases than the A.G.C.T., of being readily reproducible, and of being relatively easy to carry out.

Following damage or destruction of the myocardium due to different causes, antibodies may be produced to several myocardial antigens at the same time. Some of them are organ-specific, but others may react also with other tissues of the homologous species, or even with the organs of heterologous species (Dóbiás and Balázs, 1966; Gery and Davies, 1961 ; Gery, Davies, and Lazarov, 1964; Kaplan and Meyeserian, 1962; Osztovics and Szutrély, 1960; Osztovics and Marcsek, 1962). According to Kaplan and Meyeserian (1962), the organ-specific antigen of myocardium can be isolated by ultracentrifugation at $56,500 \mathrm{~g}$; on the other hand, Gery et al. (1964) failed to cause the heart-specific antigen to settle out at $105,000 \mathrm{~g}$ either. The unfractionated myocardial homogenate contains also such antigens as may occur in other organs as well. When we carry out the immune reactions with such antigens, then we shall get positive results with sera not only from cardiac patients. In agreement with the results published by Osztovics and Szutrély (1960), Osztovics 
et al. (1962), Osztovics and Marcsek(1962), in previous investigations we often got positive results with the unfractionated antigen in tonsillitis, upper respiratory tract catarrh or in other infectious diseases, probably because the antibodies produced against connective tissue in these conditions reacted with the heart muscle tissue homogenate used as antigen. As the diseases mentioned are common ones, in order to reduce the incidence of 'aspecific' positive reactions we tested exclusively sera from patients with disturbances of coronary circulation but without evidence indicative of the recent occurrence of infectious diseases.

The antibodies to heart muscle tissue reacted in the first place with the antigen prepared from intact parts of the heart muscle, whereas the reactions were positive in a much lower percentage when antigen prepared from the area of infarction was used. It seems that the antibodies are active against antigens, with none or very little change in structure. This statement is supported also by the observation that the reactions were positive more frequently with the antigen prepared from intact myocardium four hours after death than with the one prepared seven hours after death, as well as by the fact that autoantibodies reacting with heart muscle tissue often appear also in the sera from patients with acute coronary insufficiency and angina pectoris showing normal laboratory findings (SGOT, E.S.R.). Thus, the production of autoantibodies in coronary disease is bound not so much to changes in the autologous tissue structure as to the circumstance that the tissue antigens 'alien' to circulation should enter the blood stream from the heart muscle tissue damaged by hypoxia.

According to our results the serum factors of an autoantibody nature reacting with the homologous heart muscle tissue possess in many respects the properties of true antibodies. When coronary disease develops for the first time (primary antigenic stimulus) they become demonstrable only after a longer period of time and persist for shorter periods, whereas following repeated attacks they appear within a few days and can be demonstrated for a long time (anamnestic reaction). In more severe and more extensive affections of the heart muscle (infarctions) they occur more frequently than following attacks of angina pectoris, but in the latter cases they tend to occur more often following attacks accompanied by intense pain and/or recurring several times (the role of the quantity of the immunizing antigen). According to gel and paper electrophoretic studies (Osztovics and Kálmán, 1962; Steffen, 1959) they migrate with the immune globulins and belong first of all to the IgG group (Kaplan, Bolande, Rakita, and Blair, 1964).
The circumstance that in some cases the antibodies reacting with heart muscle tissue will appear in the serum even when the myocardial lesion is not demonstrable by other laboratory methods emphasized the diagnostic significance of immunological methods, as has been pointed out by Kleinsorge and Dornbusch (1960). It is to be noted, however, that just in those cases in which there were only one or two painful attacks during the course of the disease, frequently at least three weeks had to elapse until the antibodies could be produced in detectable quantities. This circumstance, although lessening the significance of the diagnostic value of serological tests, indicates that even in the cases of 'just passing angina complaints' the heart muscle may be so severely damaged that heart muscle antigens may enter the blood stream and initiate antibody production. These facts should be borne in mind when we treat or wish to send back to work patients with acute coronary insufficiency or angina pectoris.

We could not find anything on the basis of the clinical symptoms, laboratory findings, or course of disease that would have suggested any detrimental action by the antibodies demonstrated by the T.C.T. In the cases showing prolonged positive results in the T.C.T. neither the E.C.G. nor the condition of the heart showed any change for which the presence of antibodies could be blamed. The cause might be sought in the relatively short persistence of the autoantibodies. According to animal experiments following immunization with homologous heart muscle, pathological changes could be demonstrated in the myocardium only when immunization had been continued for six to 10 weeks at least (Davies et al., 1964; Gery et al., 1960; Kaplan, 1958; Kaplan and Craig, 1963). For the time being, we do not know what role the autoantibodies discussed are playing; they appear to be accompanying the immune processes without serving any apparent purpose.

\section{REFERENCES}

Butler, K. R., and Moeschlin, S. (1956). Helv. med. Acta, 23, 592.

Davies, A. M., Laufer, A., Gery, I., and Rosenmann, E. (1964). Arch. Path., 78, 369.

Dóbiás, G. (1963a). Orv. Hetil., 104, 587.

- (1963b). J. clin. Path., 16, 441.

—_, Ballo, T., Bertalan, T., and Loránt, O. (1965a). Magy-belorv. Arch., 6, 313. , (1965b) Z. Immun. Forsch., 129, 452.

-, and Balázs, M. (1966). Immunology in press.

Dressler, W. (1959). Arch. intern. Med., 103, 28.

Ehrenfeld, E. N., Gery, I., and Davies, A. M. (1961). Lancet, 1, 1138. Van der Geld, H. (1964). Ibid., 2, 617.

Gery, I., and Davies, A. M. (1961). J. Immunol., 87, 351

$\longrightarrow$, and Ehrenfeld, E. N. (1960). Lancet, 1, 471.

- , and Lazarov, E. (1964). Immunology, 7, 182.

Hess, E. V., Fink, C. W., Taranta, A., and Ziff, M. (1964). J. clin. Invest., 43, 886 .

Kaplan, M. H., and Meyeserian, M. (1962). J. Immunol., 88, 450. - (1958). Ibid., 80, 254, 264.

-, and Craig, J. M. (1963). Ibid., 90, 725. 
Kaplan, Bolande, R., Rakita, R., and Blair J. (1964). New Engl. J. Med., 271, 637.

Kleinsorge, H., and Dornbusch, S. (1960). Klin. Wschr., 38, 970.

Osztovics, M., and Kálmán, E. (1962). Gyermekgyógyászat, 13, 107. (1962). Acta paediat. Acad. Sci. hung., 3, 211.

Marcsek, Z., and Szász, G. (1962). Gyermekgyógyászat, 13, 97. , Mar Szutrély, G. (1960. Orv. Hetil., 101, 1481.

Polzer, K., and Steffen, C. (1958). Klin. Wschr., 36, 211.
Robinson, J., and Brigden, W. (1963). Brit. med. J., 2, 706.

Steffen, C. (1955). Klin. Wschr., 33, 134.

, and Schindler, H. (1955). Schweiz. Z. allg. Path., 18, 287.

(1959). In 1st International Symposium on Immunopathology, edited by P. Graber, and P. Miescher, p. 376, Benno Schwabe, Basle.

Szécséy, Gy., Dóbiás, Gy., and Kerekes, E. (1966). J. clin. Path., 19. 275. 